\title{
Toplesfer: Media Sederhana Untuk Mendukung Pembelajaran Demonstrasi Pada Pelajaran Geografi
}

\author{
Qo'idul Umam ${ }^{1 *}$ dan Sunaryo ${ }^{1}$
}

${ }^{1}$ MAN 2 Pati, Jawa Tengah

\section{A R T I C L E I N F O}

Article history:

Received 12 Oktober 2019

Accepted 23 Desember

2019

Available online 31

Desember 2019

\section{Kata Kunci:}

Toplesfer; Inovasi

Pembelajaran; Pelajaran

Geografi

Keywords:

Toplesfer; Learning Innocation; Geography Learning

\begin{abstract}
A B S T R A K
Sulitnya akses media pembelajaran geografi yang murah dan terjangkau sangat sulit didapatkan sehingga hal ini harus disiasati dengan baik. Padahal seyogyanya dalam pembelajaran geografi dibutuhkan alat-alat yang mendukung untuk praktikum dalam penjelasan materi. Adapun tujuan penelitian ini adalah untuk mendeskripsikan penggunaan toplesfer dalam pembelajaran geografi pada materi atmosfer. Metode yang digunakan dalam penelitian ini ialah dengan pendekatan kualitatif. Data diperoleh melalui observasi di dalam kelas pada saat pembelajaran berlangsung. Hasil penelitian menunjukkan bahwa media toplesfer merupakan alat praktikum geografi yang sederhana dengan bahan bekas yang mudah dijangkau. Hal ini memberikan alternatif dalam pemaparan materi sehingga siswa antusias dan memberikan respon positif dengan adanya toplesfer tersebut. Toplesfer dapat menjelaskan materi tentang evaporasi, kondensasi, presipitasi, tekanan udara dan awan tornado. Selain itu, pada proses pembelajaran rasa ingin tahu siswa menjadi lebih baik mengingat ada sesuatu yang baru dalam mendemonstrasikan materi pelajaran.
\end{abstract}

\section{A B S T R A C T}

Access to affordable, inexpensive media of geography is so hard to come by that it has to be carefully calibrated. Whereas generally in geography study, tools are needed that promote practicality in material explanation. And the purpose of this research is to describe the use of the toplesfer in the geographic study of atmospheric matter. The method used in this study is with a qualitative approach. Data is obtained by observation in the classroom during the learning process. Research indicates that toplesfer media is a simple Geotech tool with readily available waste products. This provides an alternative to material exposure so that students are enthusiastic and respond favorably to the toplesfer. Toplesfer can explain matter about evaporation, condensation, precipitation, air pressure, and tornado clouds. Besides, during the learning process of curiosity, students are better off, remembering that there is something new in demonstrating the lesson material.

Copyright @ Universitas Pendidikan Ganesha. All rights reserved.

\footnotetext{
* Corresponding author.

E-mail addresses: qoidulu@gmail.com
} 


\section{Pendahuluan}

Pendidikan adalah sarana utama dalam membentuk dan menciptakan sumber daya manusia yang berkualitas. Sumber daya manusia yang berkualitas dapat dilihat dari mutu pendidikan yang diselenggarakan pemerintah. Potensi sumber daya manusia yang berkualitas dapat mengembangkan pendidikan untuk dapat melaksanakan pembangunan nasional. Oleh karena itu, pendidikan mempunyai peranan penting dalam mewujudkan sumber daya manusia yang berkualitas.

Namun, perkembangan pendidikan di Indonesia saat ini, baik pendidikan formal maupun informal banyak mengalami hambatan. Salah satunya yaitu rendahnya mutu pendidikan yang berakibat rendahnya kualitas lulusan yang kompetitif (Dwisukmasurya, Lasmawan, \& Sriartha, 2019). Rendahnya mutu pendidikan salah satunya dapat dilihat dari aspek pembelajaran yang ada di sekolah-sekolah. Kegiatan pembelajaran merupakan roh pendidikan yang di dalamnya terjadi interaksi antara murid dan siswa melalui transfer of knowledge, role model, dan pengembangan karakter untuk mencapai tujuan seperti yang tertuang dalam undang-undang. Hal tersebut didukung oleh pendapat Muzakki (2015) yang menyatakan bahwa salah satu permasalahan yang sangat urgen yang dihadapi oleh dunia pendidikan yaitu masih rendahnya mutu belajar siswa dan pembelajaran bagi siswa.

Peserta didik sering dihadapkan pada permasalahan pembelajaran di dalam kelas yang cenderung membosankan dan mengekang pola pikir siswa. Siswa sering dihadapkan pada metode guru dalam menjelaskan pelajaran sangat monoton, tidak ada media yang digunakan untuk mendukung siswa dalam memahami pelajaran, suasana kelas yang tidak nyaman, dan masih banyak lagi permasalahan yang di hadapi siswa. Mereka tidak bisa menerima pelajaran dengan maksimal, akibatnya mutu pembelajaran di dalam kelas semakin lama semakin menurun.

Padahal penerapan proses pembelajaran yang inovatif dan kreatif akan memantik semangat belajar siswa. Jika dalam proses pembelajaran siswa bersemangat dan aktif, diharapkan akan terjadi multiplier effect yang positif dalam diri siswa diantaranya adalah rasa ingin tahu yang tinggi, cinta akan ilmu pengetahuan, dan berkembangnya intelektualitas peserta didik sesuai dengan kemampuan dan kapasistas masing-masing. Proses pembelajaran yang baik sudah tentu dibarengi dengan adanya media yang mudah didapat (accessable) serta model pembelajaran yang kreatif. Pemanfaatan media dipadu dengan model pembelajaran merupakan bagian yang penting dalam menyusun strategi pembelajaran yang tepat.

Pembelajaran merupakan aspek yang penting dalam pendidikan. Sudjana (2010) mengungkapkan bahwa metode pembelajaran ialah cara yang dipergunakan guru dalam mengadakan hubungan dengan siswa pada saat berlangsungnya pengajaran. (Aksa, Afrian, \& Jofrishal, 2018) menyebutkan metode pembelajaran adalah suatu cara penyampaian bahan pelajaran untuk mencapai tujuan yang ditetapkan. Sementara itu, (Wahyudin, Sutikno, \& Isa, 2010), menyatakan metode pembelajaran adalah cara-cara menyajikan materi pelajaran yang dilakukan oleh guru agar terjadi proses pembelajaran pada diri siswa dalam upaya untuk mencapai tujuan.

Pembelajaran merupakan aspek yang penting dalam pendidikan. Sudjana (2010) mengungkapkan bahwa metode pembelajaran ialah cara yang dipergunakan guru dalam mengadakan hubungan dengan siswa pada saat berlangsungnya pengajaran.

Sementara itu, (Wahyudin et al., 2010) menyatakan metode pembelajaran adalah cara-cara menyajikan materi pelajaran yang dilakukan oleh guru agar terjadi proses pembelajaran pada diri siswa dalam upaya untuk mencapai tujuan.

Sudjana (2010) mengungkapkan bahwa ada beberapa jenis metode pembelajaran yaitu: metode ceramah, metode diskusi, metode demonstrasi, metode simulasi, metode latihan, metode eksperimen, dan metode pemecahan masalah. Sudjana (2010) juga mengungkapkan bahwa metode demonstrasi adalah suatu metode mengajar memperhatikan bagaimana jalannya suatu proses terjadinya sesuatu. Lebih mengkhusus, Wahyudin et al., (2010) menjelaskan bahwa metode demonstrasi adalah pertunjukan tentang terjadinya suatu peristiwa atau benda sampai pada penampilan tingkah laku yang dicontohkan agar dapat diketahui dan dipahami oleh peserta didik secara nyata atau tiruannya. 
Hal yang sama juga dikemukakan oleh Dwisukmasurya et al. (2019) yang menyatakan bahwa media pembelajaran inovatif memungkinkan adanya partisipasi aktif baik antara siswa dengan guru dan sebaliknya, juga siswa dengan teman sebayanya. Sementara itu, metodedemonstrasi adalah cara penyajian materi pelajaran dengan mempertunjukkan secara langsung objek atau cara melakukan sesuatu untuk mempertunjukkan proses tertentu. Hal yang sama juga dikemukakan oleh Wahyudin et al. (2010) yang menyatakan bahwa metode demonstrasi adalah metode yang digunakan untuk memperlihatkan sesuatu proses atau cara kerja suatu benda yang berkenaan dengan bahan pelajaran.

Berdasarkan berbagai uraian yang telah dipaparkan maka dapat diambil kesimpulan bahwa metode demonstrasi merupakan proses dalam menjelaskan materi pelajaran kepada peserta didik dengan memperhatikan kronologis atau penyajian materi dengan mencontohkan langsung terhadap materi yang dibahas. Kaitannya dengan demontrasi yang dilakukan oleh guru harus memperhatikan materi yang dibawakan dalam pembelajaran agar dalam proses demonstrasi mudah untuk ditirukan dan diaplikasikan. Selain itu, metode demonstrasi merupakan metode yang efektif untuk menjelaskan materi kepada peserta didik karena kemudahan penjelasan yang dicontohkan langsung oleh guru.

Kaitannya dengan metode pembelajaran simulasi dalam penelitian ini, digunakanlah Toplesfer sebagai alat bantu dalam melakukan simulasi dalam pembelajaran. Toplesfer merupakan terminologis yang digunakan untuk menyebut media sederhana berbahan toples yang sudah dimodifikasi dan digunakan sebagai media untuk menerangkan dalam pembelajaran geografi pada materi atmosfer. Seperti yang kita ketahui bahwa dalam objek studi geografi terdapat berbagai materi diantaranya adalah litosfer, atmosfer, biosfer, antroposfer, dan hidrosfer.

Bumi memiliki lapisan gas yang disebut atmosfer yang berada pada ketinggian $0 \mathrm{~km}$ hingga $560 \mathrm{~km}$ dari atas permukaan Bumi. Atmosfer tersusun atas beberapa lapisan yang dapat dibedakan berdasarkan karakteristik seperti komposisi gas, suhu, dan tekanan. Transisi antara lapisan yang satu dengan yang lain berlangsung bertahap.

Sebagai media lingkungan, atmosfer berfungsi untuk menampung berbagai macam gas yang dihasilkan oleh aktivitas manusia seperti Oksigen, Karbon dioksida, dan uap air. Keberadaan berbagai macam gas tersebut apabila sesuai kadar maka tidak akan berpengaruh banyak terhadap aktivitas manusia namun sebaliknya apabila keberadaan gas-gas tersebut melebihi ukuran yang seharusnya maka dikhawatirkan dapat membahayakan umat manusia dan kehidupan di Bumi. Kaitannya dengan toplesfer, diharapkan mampu menjelaskan melalui demonstrasi salah satu sub materi atmosfer diantaranya adalah evaporasi, presipitasi, dan perbedaan tekanan udara serta kejadian angin tornado.

Rendahnya inovasi guru dalam melakukan pembelajaran akan sangat berdampak signifikan terhadap kualitas pembelajaran yang dihasilkan tak terkecuali dalam pembelajaran geografi. Sulitnya akses media pembelajaran geografi yang murah dan terjangkau sangat sulit didapatkan sehingga hal ini harus disiasati dengan baik. Padahal seyogyanya dalam pembelajaran geografi dibutuhkan alat-alat yang mendukung untuk praktikum dalam penjelasan materi.

Penerapan media pembelajaran inovatif khususnya menggunakan toplesfer merupakan suatu cara baru dalam penyampaian materi terkait berbagai fenomena atmosfer sehingga pengembanga media pembelajaran demonstrasi ini merupakan suatu hal yang penting untuk dilakukan. Beranjak dari hal tersebut, maka dipandang penting untuk mengkaji tentang inovasi baru toplesfer sebagai media sederhana untuk mendukung pembelajaran demonstrasi pada pelajaran geografi. Diharapkan dengan adanya media pembelajaran ini dapat meningkatkan kualitas pemahaman dan proses pendalaman materi yang ada khususnya pada materi atmosfer pada pelajaran geografi.

\section{Metode}

Penulisan dalam penelitian ini menggunakan pendekatan kualitatif dengan melakukan kajian empiris dan studi kepustakaan. Teknik pengumpulan data dilakukan dengan observasi di 
kelas yang dilakukan percobaan pembelajaran dengan alat toplesfer, sedangkan teknik analisis data reduksi data yang kemudian dianalisis dengan analisis deskriptif

\subsection{Tahapan pembuatan alat}

Proses pembuatan toplesfer memerlukan alat yang mencakup toples plastik, obat nyamuk, lilin, korek api dan bahan yang mencakup air panas dan ganta serta lem seperti terlihat pada Gambar 1.
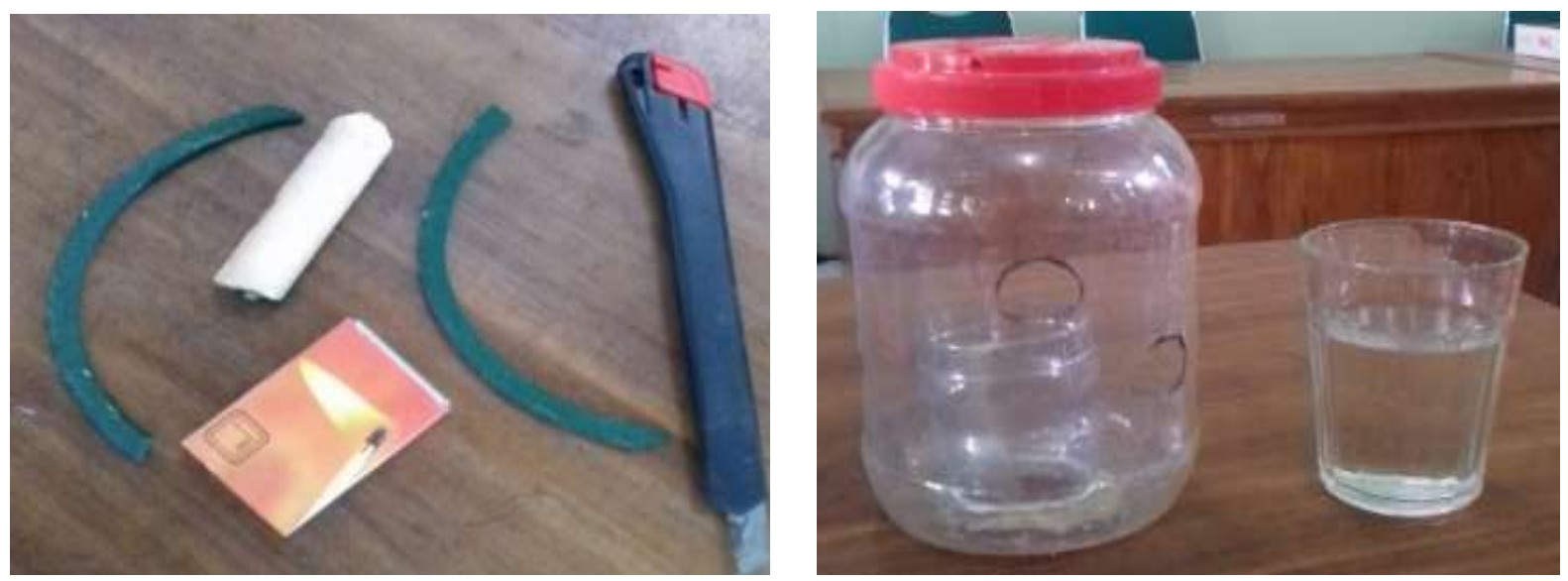

Gambar 1. Alat Dan Bahan Pembuatan Toplesfer

\subsection{Langkah-langkah pembuatan toplesfer}

Berikut adalah proses pembuatan toplesfer;

1) Siapkan alat dan bahan-bahan

2) Lubangi toples bagian bawah ukuran sedang

3) Pasang botol kecil yang sudah dipotong kemudian tempelkan/gabungkan dengan lubang toples menggunakan lem

4) Buat 3 lubang di sisi toples dengan skala lubang kecil, sedang dan besar

\subsection{Prosedur kerja dalam demonstrasi alat}

\section{Pembuatan evaporasi, kondensasi dan presipitasi}

Hal yang perlu dilakukan ialah;

1) Persiapkan toplesfer

2) Masukkan air panas yang telah disiapkan ke dalam toplesfer

3) Tutup toples dengan rapat

4) Tunggu sebentar hingga titik air menempel di bagian samping dan atas toples (yang disebut evaporasi)

5) Setelah terjadinya evaporasi jika air yang menguap (terjadi kondensasi) menetes kembali, maka itu adalah hujan (presipitasi)

\section{Perbedaan tekanan udara}

Hal yang perlu dilakukan ialah;

1) Toples tetap berisi air hangat

2) Tutup toples bagian atas

3) Nyalakan obat nyamuk untuk menghasilkan asap

4) Letakkan obat nyamuk di sebelah lubang toples yang dalam keadaan tertutup (asap dipastikan tidak akan masuk karena perbedaan tekanan udara)

\section{Angin tornado}

1) Toples tetap berisi air hangat

2) Jangan pasang tutup toples

3) Nyalakan 3 obat nyamuk kemudian letakkan di sebelah lubang toples yang sudah dibuat 


\subsection{Aplikasi praktis dalam pembelajaran}

Langkah-langkah penggunaan media dan cara penggunaan media Toplesfer dalam pelajaran geografi berbasis pembelajaran demonstrasi pada materi atmosfer adalah sebagai berikut.

1) Guru mengucap salam pembuka dan mengabsensi kehadiran siswa. Dilanjutkan dengan doa bersama.

2) Guru melakukan apersepsi dengan melakukan tanya jawab kepada siswa terkait materi atmosfer.

3) Guru memberikan motivasi dan menjelaskan tujuan pembelajaran yang akan dicapai.

4) Guru menyampaikan materi tentang siklus hidrologi dan menunjukkan contohnya.

5) Siswa dibagi dalam kelompok yang terdiri dari 5 orang.

6) Guru menyampaikan tugas yang harus dikerjakan oleh setiap kelompok yang sekaligus setiap kelompok sudah menyiapkan bahan dan alat untuk merangkai toplesfer

7) Guru menjelaskan dan memberikan contoh cara menggunakan media toplesfer untuk menerangkan/mendemonstrasikan proses terjadinya hujan, awan, perbedaan tekanan udara dan angin.

8) Siswa melakukan tahap SIMULASI:

9) Siswa melakukan eksperimen sendiri dengan alat yang dibawa/sudah disiapkan dari rumah.

10) Siswa diperkenankan untuk melakukan percobaan diluar prosedur baku yang telah ditetapkan dengan tujuan mengeksplorasi dengan metode sendiri

11) Siswa mencatat dan mengamati hasil dari fenomena yang telah dibuat melalui media toplesfer

\section{Hasil dan Pembahasan}

Tantangan perkembangan dunia pendidikan selalu menjadi trend dan topik yang menarik untuk diperbincangkan. Sistem kurikulum hingga pelaksanaan pembelajaran selalu mengalami perubahan baik pada tataran teori maupun pelaksanaannya. Begitupun halnya dalam pendidikan geografi. Pada tingkat sekolah dan perguruan tinggi, pembelajaran geografi juga selalu menarik untuk dibahas. Hasil belajar geografi yang maksimal, segala cara akan ditempuh. Baik melalui penerapan model-model pembelajaran hingga pendekatan pembelajaran yang bervariatif. Keberhasilan pembelajaran geografi tidak hanya didukung oleh keahlian guru dalam menyajikan materi tetapi guru dapat mengkombinasikan materi yang diajarkan dalam kehidupan nyata peserta didik. Kemampuan guru geografi mengorganisasikan dalam pembelajaran, penguasaan atas konsep-konsep yang diajarkan dan keterkaitan materi ajar dengan kehidupan nyata siswa adalah sebagian kecil dari hal-hal yang perlu dimiliki guru di dalam membelajarkan geografi. Jadi, keberhasilan pembelajaran geografi yang berlangsung di sekolah sangat erat kaitannya dengan kompetensi guru (Setiawan, Maryani, \& Nandi, 2018).

Pada pemaparan bagian ini, akan dipaparkan untuk menguraikan dan mengelaborasi secara deskriptif tentang peran guru dan kondisi pembelajaran di kelas ketika dalam pembelajaran menggunakan media toplesfer. Hasil yang dapat dilihat dari dari adanya proses penggunaan media toplesfer dalam pembelajaran ialah motivasi anak dalam belajar meningkat. Hal ini dapat dilihat pada indikator anak-anak yang antusias, tenang dan bahkan bertanya-tanya ketika guru akan menerangkan dan mendemostrasikan alat yang sudah dibawa. Selain itu, karena proses pembelajaran geografi yang mayoritas pembelajarannya abstrak karena hanya ceramah dan diskusi, siswa tidak memiliki kelengkapan imanjinasi untuk membayangkan materi-materi yang diterangkan karena minimnya pengalaman.

Pembelajaran geografi sebagian besar menggunakan desain pembelajaran dengan pendekatan behavioristik belum menekankan perspektif spasial (Khafid, 2007). Strategi pembelajarannya memakai format penyampaian informasi, karena teori ini menganggap bahwa belajar ialah perolehan pengetahuan. Mengajar ialah memindahkan pengetahuan kepada siswa, belum menekankan aktivitas siswa membangun sendiri pengetahuannya (Ertmer \& Newby, 2013). Hasil pengawasan di sekolah, ternyata guru geografi masih tetap sebagai sumber belajar paling dominan, belum memanfaatkan sumber belajar yang beragam. Pembelajaran geografi 
sebagian berpusat pada kegiatan mendengar dan menghafal, belum mengarah pada kegiatan belajar aktif dan kreatif, artinya siswa membangun sendiri wawasan geografinya, bekerja, dan berpikir seperti seorang geograf. Supaya proses dan hasil mencapai optimal, siswa harus menguasai prinsip belajar konstruktivistik dan peran guru sebagai motivator, fasilitator, dan konsultan (Khafid, 2019).

Hal ini didukung oleh pendapat Aksa et al. (2018) yang menyatakan bahwa dalam konteks pendidikan geografi, fakta menunjukkan bahwa kondisi pembelajaran geografi yang berlangsung di sekolah Indonesia mulai tingkat dasar sampai menengah cenderung menghafal konsep (nama sungai, danau, negara, ibukota, dll). Hal ini terlihat dari buku teks yang beredar di pasaran dan digunakan oleh guru dan siswa dalam pembelajaran didominasi oleh fakta/data dan konsep. Maka dari itu, dengan adanya toplesfer siswa menjadi lebih mengerti secara detail proses-proses gejala alam yang terjadi secara kontekstual.

Hasil temuan ini sejalan dengan penelitian (Baiquni, 2016) dengan hasil media belajar inovatif guru dalam menjelaskan materi yang susah, yang dibuktikan dengan adanya peningkatan hasil belajar siswa yang menggunakan media inovatif dibandingkan penggunaan media konvensional seperti terlihat pada Gambar 2.

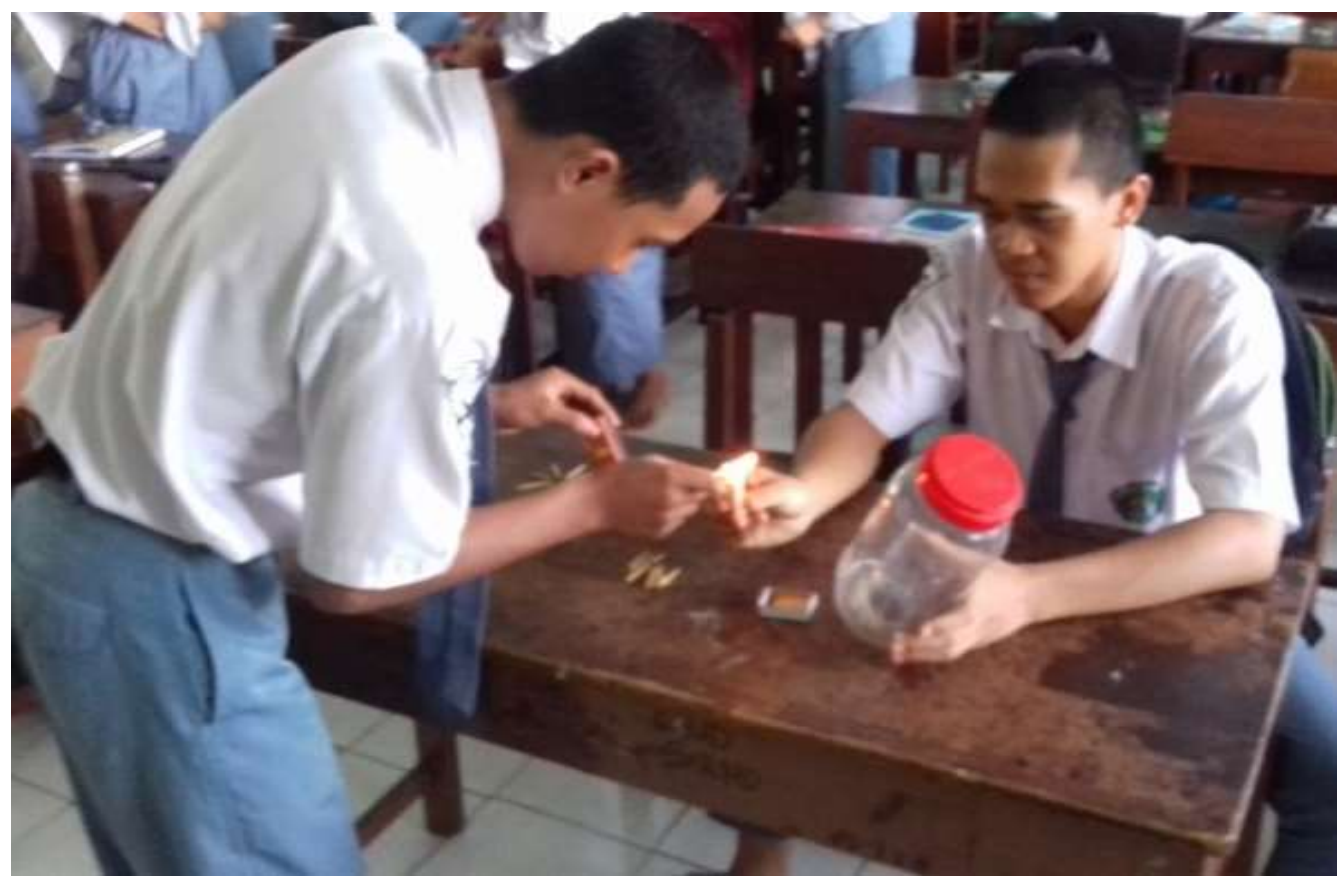

Gambar 2. Potret Simulasi Dalam Pembelajaran Dengan Media Toplesfer

Hal lain yang perlu diungkapkan ialah dengan adanya media toplesfer pembelajaran di kelas menjadi lebih hidup karena setiap kelompok melakukan eksplorasi dan mendemonstrasikan sendiri hasil dari karya yang telah dibuat. Meskipun belum ada data absolut yang menyatakan bahwa toplesfer sangat membantu dalam penjabaran materi atmosfer akan tetapi respon siswa-siswa menunjukkan gejala yang demikian.

Suatu inovasi baru dalam pembelajaran geografi yang memberikan peluang terjadinya proses aktif siswa mengonstruksi sendiri wawasan geografi, memanfaatkan sumber belajar yang beragam, adanya peluang siswa melakukan percobaan atau studi archival melalui penggunaan media secara optimal, dan berpikir geografis yang divergen ialah pembelajaran geografi dengan pendekatan konstruktivistik. Pendekatan konstruktivistik ini sesuai dengan esensi manusia sebagai seorang geograf. Pendekatan konstruktivistik dalam tujuan pembelajaran geografi menekankan belajar bagaimana belajar, menciptakan pemahaman baru, mengkreativitas dalam konteks nyata, dan mendorong siswa untuk berpikir ulang. Siswa juga melakukan studi/kerja lapangan didukung studi archival melalui pemanfaatan peta sehingga mampu berpikir dan bertindak secara geografis. 
Tuntutan abad pengetahuan dan globalisasi, pembelajaran harus diarahkan bagaimana membelajarkan dengan menekankan proses aktif siswa membangun sendiri wawasan geografi. Guru memposisikan sebagai salah satu sumber belajar, memberi peluang kepada siswa memanfaatkan sumber belajar secara beragam dan berkolaborasi, belajar secara proaktif dan kreatif dalam perspektif geografi. Pembelajaran geografi yang memenuhi karakteristik dimaksud di atas dike-nal dengan pendekatan konstruktivistik. Untuk maksud tersebut, perlu dilakukan pengembangan desain pembelajaran geografi dengan menggunakan pendekatan konstruktivistik yang berawal dari merancang produk, uji coba produk, dan merevisi produk yakni berupa model DPK dan perangkat pembelajaran geografi.

Sejalan dengan penelitian ini, hasil riset yang dilakukan oleh Widyastuti, Respati, \& Suparmini (2017) mengungkapkan bahwa terdapat hubungan yang positif antara intensitas penggunaan Laboratorium Geografi yang di dalamnya terdapat berbagai alat yang digunakan untuk pratikum dengan hasil belajar geografi siswa SMA di Kabupaten Bantul.

Keberhasilan pengembangan media pembelajaran dalam meningkatkan aktivitas dan prestasi belajar siswa telah ditunjang oleh berbagai penelitian, diantaranya Syahrani (2018) yang menggunakan media permainan untuk meningkatkan aktivitas belajar siswa dari $21 \%$ meningkat menjadi 87,6\%. Penelitian Afandi (2015) dengan menggunakan media pembelajaran inovatif yang dikembangkan dengan model simulasi menunjukkan bahwa dalam meningkatkan hasil belajar sebesar $40 \%$ pada pembelajaran IPS.

Kajian ini mendukung hasil penelitian Mustaji (2010) tentang model pembelajaran. Mustaji (2010) mengemukakan bahwa model pembelajaran sebagai abstraksi sesuatu yang dipakai untuk membantu siswa memahami suatu objek atau peristiwa yang tidak dapat dilihat atau dialami secara langsung. Model umumnya tidak menggambarkan secara detail kenyataan, tetapi hanya bagian tertentu yang penting atau merupakan sosok kunci atau hal-hal yang relevan saja. Model pembelajaran pada dasarnya dapat digunakan untuk menyusun kurikulum, merancang bahan pelajaran, dan menuntun pelajaran di kelas atau pada kondisi lainnya. Dalam pengertian inilah disebut model pembelajaran yang akan dikembangkan.

Maka penggunaan alat-alat dalam pembelajaran geografi dinilai sangat mendukung untuk melengkapi proses penjelasan materi di dalam kelas. Hal tersebut dikarenakan siswasiswi mendapatkan pengalaman baru dalam memahami konsep-konsep yang sebelumnya selalu dijelaskan dengan ceramah (konvensional) dan diubah dengan penjelasan konkrit dipadu dengan simulasi secara mandiri sehingga menambah semangat siswa dalam pembelajaran. Karakter kemandirian dan tanggungjawab harus menjadi habituasi bagi pesera didik. Habituasi adalah proses yang terjadi ketika nilai-nilai sosial dihayati oleh manusia, tercipta melalui proses sosialisasi nilai-nilai yang berlangsung lama, mengendap menjadi cara berfikir dan pola perilaku yang kemudian menetap pada diri manusia itu. Kemudian habitus berlangsung dengan cara tahan lama, sistematis dan non mekanis (Hidrawati, 2017). Habituasi nilai karakter tanggungjawab dan kemandirian menjadi penting bagi siswa untuk mempersiapkan mereka terjun dalam masyarakat. sikap kemandirian itu tidak mudah bergantung pada orang lain dalam memenuhi kebutuhannya atau mengatasi persoalannya terutama di lingkungan pendidikan. Menarik mengkaji hal tersebut, karena kenyataannya dalam proses pendidikan di sekolah yang tidak demokratis dan cenderung memberikan indoktrinasi tanpa argumentasi kepada peserta didik, akan menghambat kemandirian mereka. Demikian juga proses pendidikan yang menekankan pentingnya pemberian sanksi atau hukuman juga dapat menghambat perkembangan kemandirian peserta didik. Sebaliknya, proses pendidikan yang lebih menekankan pentingnya penghargaan terhadap potensi anak, pemberian reward, dan penciptaan kompetisi positif akan memperlancar kemandirian anak (Lestari, Setiawan, \& Puspitaningrum, 2018).

Penelitian yang sejalan dengan kajian mengenai penanaman, penguatan dan habituasi nilai karakter siswa di sekolah diantaranya, mengenai penanaman, penguatan dan habituasi nilai karakter di sekolah, diantaranya (Wuryadani, Fathurrohman, \& Ambarwati, 2016) meneliti implementasi pendidikan karakter kemandirian di Muhammadiyah Boarding School. Dahliyana (2017) mengkaji mengenai penguatan pendidikan karakter melalui kegiatan ekstrakurikuler di sekolah. 
Media pembelajaran geografi (MPG) adalah segala bentuk sesuatu baik barang asli maupun hasil tiruan, manipulasi, modifikasi dan simplikasi yang dapat digunakan sebagai perantara dalam proses pembelajaran geografi agar penyampaian materi ajar dari suatu topik pembelajaran geografi dapat diterima dengan mudah dan diserap oleh peserta didik sehingga dapat meningkatkan efektivitas dan efisiensi pencapaian tujuan pembelajaran geografi sesuai dengan rancangan skenario mengajar pendidik (Pramita, 2016).

Pembelajaran sebagai suatu proses pengembangan pengetahuan, keterampilan, pengembangan tingkah laku melibatkan interaksi individu, fasilitas-fasilitas fisik, psikologis, metode pembelajaran, media pembelajaran, dan teknologi. Dengan demikian belajar adalah proses yang melibatkan proses seleksi, pengaturan, penyampaian pesan yang pantas kepada lingkungan dan bagaimana cara pebelajar berinteraksi dengan informasi tersebut. Maka pemilihan media sebaiknya tidak dilepaskan dalam konteks bahwa media merupakan komponen dari sistem pembelajaran secara utuh. Dengan demikian faktor-faktor seperti karakteristik siswa, strategi dan metode pembelajaran, saran dan prasarana, alokasi waktu, dan sumber belajar, serta prosedur penilaian juga perlu dipertimbangkan (Sidi \& Sudrajat, 2014).

Materi pembelajaran geografi di sekolah memerlukan media pembelajaran yang lebih banyak dan variatif untuk meningkatkan efektivitas dan efisiensi penyampaian tujuan pembelajaran geografi. Materi-materi pembelajaran geografi seperti gejala-gejala geosfera dan proses-proses alamiah adalah situasi nyata yang tidak selalu dapat disediakan oleh guru baik di kelas maupun di lingkungannya. Oleh karena itu MPG harus dapat memberikan gambaran atau situasi nyata atau contoh situasi buatan dalam sajian yang representatif. Konsep materi pembelajaraan geografi yang luas (seperti: gunung berapi, gempa bumi, iklim, laut, sungai, dan danau) dapat divisualisasi dalam miniatur, model, maupun gambar yang disajikan secara visual, audio atau bahkan audio-visual (Siagian \& Lingin, 2012). Selain itu MPG yang digunakan juga harus konstekstual, interaktif, dan menarik (Sumintono, 2013). Media pembelajaran secara umum diklasifikasi menjadi tiga kelompok, yaitu: 1) persepsi panca indera: media audio, media visual, dan media audio-visual; 2) sasaran pengguna: individu, kelompok kecil, dan massal; dan 3) cara penggunaan: konvensional/sederhana dan mutahir/kompleks.

Beberapa penelitian sejenis menunjukan bahwa pemanfaatan media pembelajaran dapat meningkatkan hasil belajar geografi. Pemanfaatan media pembelajaran ebook \& textbook (Sufia \& Kurniawati, 2013), media pembelajaran interaktif berbasis perangkat lunak Macaromedia Flash Professional 8.0 (Siagian \& Lingin, 2012), kartu hidrologi (Shofifah \& Sigit, 2013) mampu meningkatkan hasil belajar geografi di SMA. Lebih lanjut, pemanfaatan multimedia yang dipadukan dengan metode pembelajaran inkuiri terbimbing terbukti meningkatkan efektivitas pembelajaran, minat dan pemahaman siswa (Wahyudin et al., 2010). Selain itu, pemanfaatan media pembelajaran berbasis perangkat lunak Power Point dapat meningkatkan aktivitas belajar, dan sikap siswa hampir 20\% dari penilaian awal (Sidi \& Sudrajat, 2014).

Banyak penelitian sejenis yang menunjukkan adanya kendala-kendala yang dihadapi dalam pengadaan media pembelajaran di sekolah, antara lain: dana dan keberadaan ruangan khusus untuk menyimpan media pembelajaran (Setianingsih, Banowati, \& Santoso, 2013; Yudi, 2012) akses terbuka terhadap media, perawatan media, tenaga khusus yang mengelola media pembelajaran, dan literasi teknologi yang dimiliki oleh guru.

Pembangunan laboratorium geografi belum menjadi prioritas utama sekolah. Berbeda dengan laboratorium MIPA ataupun laboratorium bahasa yang sudah menjadi prioritas pembangunan di SMA. Laboratorium geografi dapat digunakan oleh siswa ataupun guru dalam rangka peningkatan kualitas pembelajaran geografi. Selain itu, laboratorium geografi juga dapat digunakan sebagai tempat penyimpanan MPG yang dimiliki oleh sekolahan. Materi-materi geografi yang bersifat abstrak, teknis, dan padat subtansi (seperti: konsep \& aspek geografi, geosfera, biosfera, antrosfera, pemetaan, penginderaan jauh \& sistem informasi geografi; dan wilayah \& perwilayahan) perlu diimbangi dengan keberadaan media pembelajaran dan laboratorium.

\section{Simpulan dan Saran}


Berdasarkan hasil penelitian dan pembahasan maka dapat disimpulkan bahwa dalam menguraikan materi atmosfer pada pembelajaran geografi toplesfer sangat membantu mempermudah pemahaman siswa dalam memahami dan mendalami pengetahuan tentang atmosfer. Hal ini dibuktikan dengan adanya antuasiasme dan respon positif yang ditunjukkan oleh siswa pada saat pembelajaran.

Adapun saran yang dapat peneliti berikan sebagai berikut: Bagi peneliti, masih perlu dilakukan kajian yang mendalam melalui riset tentang keberhasilan dan kebermanfaatan toplesfer dalam media pembelajaran geografi. Bagi guru geografi, pemanfaatan media yang tepat merupakan kunci keberhasilan dalam pembelajaran sehingga diharapkan mampu untuk mendongkrak rasa ingin tahu dan minat siswa terhadap pembelajaran geografi.

\section{Daftar Rujukan}

Afandi, R. (2015). Pengembangan Media Pembelajaran Permainan Ular Tangga untuk Meningkatkan Motivasi Belajar Siswa dan Hasil Belajar IPS di Sekolah Dasar. Jurnal Inovasi Pembelajaran, 1(1), 77-89.

Aksa, F. I., Afrian, R., \& Jofrishal. (2018). Analisis Konten Buku Teks Geografi SMA Menggunakan Model Beck \& Mckeown. Jurnal Pendidikan Geografi, 23(1), 1-8.

Baiquni, I. (2016). Penggunaan Media Ular Tangga Terhadap Hasil Belajar Metematika. JKPM, $1(2), 193-203$.

Dahliyana, A. (2017). Penguatan Pendidikan Karakter Melalui Kegiatan Ekstrakurikuler Di Sekolah. Sosio Religi Jurnal Pendidikan Umum/Nilai, 15(1), 1-10.

Dwisukmasurya, P. M. D., Lasmawan, I. W., \& Sriartha, I. P. (2019). Pengembangan Media Pembelajaran Geografi Berbentuk Permainan Ular Tangga Berbantuan Leaflet Di Sma Dwijendra Denpasar. Media Komunikasi Geografi, 20(1), 34-43.

Ertmer, P. A., \& Newby, T. J. (2013). Behabiorrism, Cognitivism, Constructivism Comparing Critical Features From an Instructional Design Perspective. Performance Improvement Quarterly, 26(2), 43-71.

Hidrawati. (2017). Sosialitas. Jurnal Ilmiah Pendidikan Sosiologi Antropologi, 1(1), 1-10.

Khafid, S. (2007). Profil Guru Geografi yang Profesional dalam Membangun Siswa Berperilaku Konstruktivis. Jurnal Geografi Dan Pengajarannya, 6(11), 580-592.

Khafid, S. (2019). Pengembangan Desain Pembelajaran Geografi dengan Pendekatan Konstruktivistik. Jurnal Ilmiah Ilmu Sosial, 5(1), 1-12.

Lestari, P., Setiawan, A., \& Puspitaningrum, A. (2018). Urgensi Habituasi Nilai Karakter Kemandirian Dan Tanggung Jawab Peserta Didik Sekolah Menengah Keguruan. Jurnal Ilmiah Ilmu Sosial, 4(2), 114-119.

Mustaji. (2010). Pengembangan Model Pembelajaran Berbasis Masalah dengan Pola Belajar Kolaborasi (Model PBMPK). Jurnal Pendidikan \& Pembelajaran, 17(2), 187-200.

Muzakki, H. (2015). Managing Learning for Quality Improvement (Mengelola Pembelajaran untuk Peningkatan Mutu). An-Nuha, 2(2).

Pramita, A. (2016). Pengembangan Media Permainan Ular Tangga Pada Materi Senyawa Hidrokarbon Kelas XI SMA untuk Meningkatkan Pemahaman Konsep Siswa. Unesa Journal of Chemical Education, 5(2), 336-344.

Setianingsih, S. W., Banowati, E., \& Santoso, A. B. (2013). Ketepatan Pemilihan Dan Penggunaan Media Pembelajaran Geografi SMA Negeri Di Kabupaten Jepara. Edu Geography, 1(2), 5762.

Setiawan, U., Maryani, E., \& Nandi. (2018). Pedagogical Content Knowledge (PCK) Guru Geografi SMA. Jurnal Ilmiah Ilmu Sosial, 4(1), 12-21.

Shofifah, A., \& Sigit, B. (2013). Pengembangan Media Kartu Hidrologi Untuk Mata Pelajaran Geografi Pada Pokok Bahasan Hidrosfer Dan Dampaknya Terhadap Kehidupan Di Muka Bumi Kelas X SMA Negeri 1 Driyorejo, Gresik. Swara Bumi, 2(3), 195-202.

Siagian, S., \& Lingin. (2012). Pengembangan Media Pembelajaran Interaktif Pada Mata Pelajaran Geografi. Jurnal Teknologi Pendidikan, 5(1), 22-30. 
Sidi, P., \& Sudrajat, A. (2014). Pembelajaran Model STS Berbantuan Media Untuk Meningkatkan Aktivitas, Sikap, Dan Hasil Belajar IPS. Harmoni Sosial, 1(21), 79-189.

Sudjana, N. (2010). Penilaian Hasil Proses Belajar Mengajar. Bandung: Remaja Rosdakarya.

Sufia, R., \& Kurniawati, A. (2013). Pengaruh Penggunaan Media E-Book Dengan Textbook Terhadap Hasil Belajar Pada Materi Biosfer Kelas XI Di SMA Negeri 1 Muncar. Swara Bhumi, 2(1), 142-150.

Sumintono, B. (2013). Sekolah Unggulan: Pendekatan Pengembangan Kapasitas Sekolah. Jurnal Manajemen Pendidikan, 2(1), 1-19.

Syahrani, Z. (2018). Penerapan Media Pembelajaran Permainan Ular Tangga Untuk Meningkatkan Aktivitas Belajar Peserta Didik Kelas XI.MIPA.2 SMAN 7 Padang. Jurnal Pendidikan Dan Teknologi Informasi, 5(1), 87-98.

Wahyudin, Sutikno, \& Isa, A. (2010). Keefektifan Pembelajaran Berbantuan Multimedia Menggunakan Metode Inkuiri Terbimbing Untuk Meningkatkan Minat Dan Pemahaman Siswa. Jurnal Pendidikan Fisika Indonesia, 6(1), 58-62.

Widyastuti, Respati, \& Suparmini. (2017). Pemanfaatan Laboratorium Geografi untuk Pembelajaran Geografi SMA (Kasus pada SMA di Kabupaten Bantul - Yogyakarta). In Prosiding Seminar Nasional Pendidikan Geografi FKIP UMP.

Wuryadani, W., Fathurrohman, \& Ambarwati, U. (2016). Implementasi Pendidikan Karakter Kemandirian Di Muhammadiyah Boarding School. Cakrawala Pendidikan, 16(1), 1-10.

Yudi, A. A. (2012). Pengembangan Mutu Pendidikan Ditinjau Dari Segi Sarana Dan Prasarana (Sarana Dan Prasarana PPLP). Cerdas Sifa, 1(1), 1-9. 